4. Молодежный экстремизм - социальная и правовая проблема общества: научно-аналитический обзор. - Белгород: Бел ЮИ МВД России. 2010. С. 59.

5. Вехов И.В. Экстремизм как объект социологического исследования // Известия Российского государственного педагогического университета имени А.И. Герцена. 2009. № 111. С.284-289.

6. Бурсевич. В.В. Взаимодействие идеологии и языка как проблема дискурс-анализа // Вестник БГУ. Серия 3. История. Философия. Психология. Политология. Социология. Экономика. Право. 2011. № 3. C. 40-44.

7. Шевченко А.Ю. Дискурс-анализ политических медиа-текстов // Политические исследования. 2002. № 6 [Режим доступа: http://www.politstudies.ru/N2004fulltext/2002/6/3.htm].

\title{
Мутьева В.В. \\ Понятие «мировой порядок» в рамках теории политического реализма
}

УрФУ им. ПервогоПрезидентаРоссии Б.Н. Ельцина (Россия, Екатеринбург)

doi:10.18411/spc-01-12-2017-07

idsp: 000001:spc-01-12-2017-07

В XXI веке возобновились дискуссии о мировом порядке и стали особенно актуальными после провозглашения Соединенными Штатами Америки в 2002 г. своего глобального лидерства и порядкоформирующей роли в мире. До сих пор в научной литературе нет общего определения понятиюмирового порядка, однако, сформировалось несколько подходов к его интерпретациям.

В рамках реалитического подхода «мировой порядок» рассматривалиР. Арон, X. Булл, К. Уолтц. Основное внимание исследователи уделяли межгосударственным отношениям, которые основываются на соотношении потенциалов между сверхдержавами. Реалисты утверждают, что порядок формируется великой державой, и предлагают два подхода к формированию мирового порядка:

- баланс сил;

- гегемония.

Порядок, основанный на принципе баланса сил базируется на анархии ипредполагает отсутствие преобладающей политической власти. В таких условиях главной целью государств является их безопасность, которая обеспечивается благодаря четкому соблюдению общих договоренностей и принципов среди мирового сообщества.

Вторая теория утверждает, что мировой порядок формируется сверхдержавой, которая использует инструменты силы и власти для поддержания своего главенствующего положения.Управление мировым порядком гегемоном происходит за счет использования угроз, военной мощи, контроля над сырьем, выгодных экономических и технологических условий, так что, другие государства соглашаются с порядком, управляемым единолично другим государством.

Теория формирования гегемонического порядка характеризуется четкой иерархией среди государств, которые управляются одной или несколькими сверхдержавами. Гегемоническая теория и теория баланса сил основаны на распределении власти. Мировой порядок, основанный на балансе сил является более предсказуемым, где государства отстаивают свои собственные интересы и не находятся под властью самого сильного. Гегемонический порядок отличается тем, что представлен необходимостю накопления власти и мощи вокруг одного или группы государств, а уровень авторитета соответствует возможности сверхдержавы создать стабильный порядок.

После распада Советского Союза установился гегемонический мировой порядок, так как были созданы благоприятные условия для того, чтобы крупнейшая держава в мире - Соединенные Штаты могли беспрепятственно распространять свою силу по всему миру. Россия столкнулась с серьезным политическим, экономических и 
социальным кризисами, в то время как США автоматически получили статус единственной сверхдержавы, способной единолично управлять мировым порядком.

Дипломат и эксперт в области международных отношений Г. Киссинджер определяет мировой порядок как «состояние конкретного региона или цивилизации, в рамках которых действует комплекс договоренностей, который считается применимым ко всему миру в целом». Данное понимание понятия предполагает создание определенной системы принципов и правил на территории одного или нескольких государств, которые считаются универсальными для того, чтобы этим нормам следовали и другие государства. Выходит, что мировой порядок по Г. Киссинджеру уже в самом определении понятия сводится к управлению самым влиятельным. Особую роль в формировании мирового порядка Г. Киссинджер отводит Соединенным Штатам, проникнутым убеждением, что принципы внутренней политики США являются универсальными для всего мира.

Американский политолог 3. К. Бжезинский, в том числе, утверждает, что США это единственная мировая держава, способная управлять мировым порядком. Г. Киссинджер и 3.К. Бжезинский считают, что формирование мирового порядка должно приспосабливался к новым международным процессам, при этом, смягчать существующие противоречия, сохраняя за Соединенными Штатами лидирующие позиции.

Говоря о российских исследователях, необходимо отметить вклад в развитие определения мирового порядка А.Д. Богатурова, Т.А. Шаклеиной, А. И. Уткина. Специалист по международным отношениямА. Д. Богатуров считает, что мировой порядок воплощается в отношениях между акторами международных отношений, в то время как международный порядок представляет собой устройство международных отношений, которое призвано обеспечить потребности государств и их безопасность. Кроме того, А.Д. Богатуров полагает, что международный порядок строится на четкой иерархии государств и характеризуется соотношением потенциалов между собой и стремлением к расширению сферы влияния. Говоря о природе иерархии современного международного порядка, исследователь относит на лидирующее положение Соединенные Штаты, которые являются руководящим звеном иерархии и единственным государством, способным влиять на международные процессы.

Российский полтитолог Т.А. Шаклеина считает, что истинный мировой порядок должен выражаться в добровольном согласии мирового сообщества с целями, задачами и методами обеспечения его стабильности. По мнению, Т.А. Шаклеиной, Соединенные Штаты провозгласили себя глабальным лидером, однако, их внешняя политика скорее соответствует поведению гегемона, отличающейся явными элементами давления. Исходя из вышесказанного, автор убеждена в гегемонической форме современного миропорядка.

Российский политолог А.И. Уткин характеризует современную мировую систему как однополюсную во главе с США. По его мнению, такой миропорядок обеспечивается за счет экономического доминирования, военной мощи и культурной привлекательности страны-гегемона

Подводя итог выявлению понятия мирового порядка, необходимо отметить, что на современном этапе не сформулировано общего определения, которое бы в полной мере отражало все аспекты международной деятельности государств и их роли в мирорегулировании. Тем не менее, в рамках теории политического реализма, большинство исследователей считают современный мировой порядок гегемоническим и закрепляют за Соединенными Штатами роль единственного могущественного государства, способного регулировать международные процессы и межгосударственные отношения.

$$
* * *
$$

1. IkenberryG.John. Power and liberal order: America's postwar world order in transition // International Relations of the Asia-Pacific Volume 5 (2005). URL: https://doi.org/10.1093/irap/lci112 
2. Bull Hedley. The Anarchical Society: A Study of Order in World Politics. Introduction and Chapters 1-2. 1977. URL: http://www.olivialau.org/ir/archive/bul2.pdf

3. Waltz K. Theory of International Politics. Anarchic Structures and Balances of Power. 1979. URL: http://www3.nd.edu/ ggoertz/grdir/waltz1979chp6.pdf

4. Баталов Э.Я. Мировое развитие и мировой порядок. Анализ современных американских концепций / Э. Я. Баталов. - М. : РОССПЭН, 2005. - 374c.

5. Киссинджер Г. Мировой порядок. М.: АСТ, 2016. - 512 с.

6. Бжезинский 3.К. Великая шахматная доска: главенство Америки и её геостратегические императивы. М.,1998. URL: http://lib.ru/POLITOLOG/AMERICA/bzhezinskij

7. Современная мировая политика. Прикладной анализ / Отв. ред. А.Д. Богатуров. М.: Аспект Пресс, 2009, 2010. 588 c.

8. Шаклеина T.A. Лидерство и современный мировой порядок. [Электронный ресурс] // URL: http://www.intertrends.ru/forty-third/Shakleina.pdf

9. Уткин А. И. мировой порядок ХХІ века. М.: «Эксмо», 2002. 